NBER WORKING PAPER SERIES

\title{
THE IMPORTANCE OF NONTRADABLE GOODS' PRICES IN CYCLICAL REAL EXCHANGE RATE FLUCTUATIONS
}

\author{
Ariel Burstein \\ Martin Eichenbaum \\ Sergio Rebelo \\ Working Paper 11699 \\ http://www.nber.org/papers/w11699 \\ NATIONAL BUREAU OF ECONOMIC RESEARCH \\ 1050 Massachusetts Avenue \\ Cambridge, MA 02138 \\ October 2005
}

The views expressed herein are those of the author(s) and do not necessarily reflect the views of the National Bureau of Economic Research.

(C)2005 by Ariel Burstein, Martin Eichenbaum, and Sergio Rebelo. All rights reserved. Short sections of text, not to exceed two paragraphs, may be quoted without explicit permission provided that full credit, including (C) notice, is given to the source. 
The Importance of Nontradable Goods' Prices in Cyclical Real Exchange Rate Fluctuations Ariel Burstein, Martin Eichenbaum, and Sergio Rebelo

NBER Working Paper No. 11699

October 2005

JEL No. F31

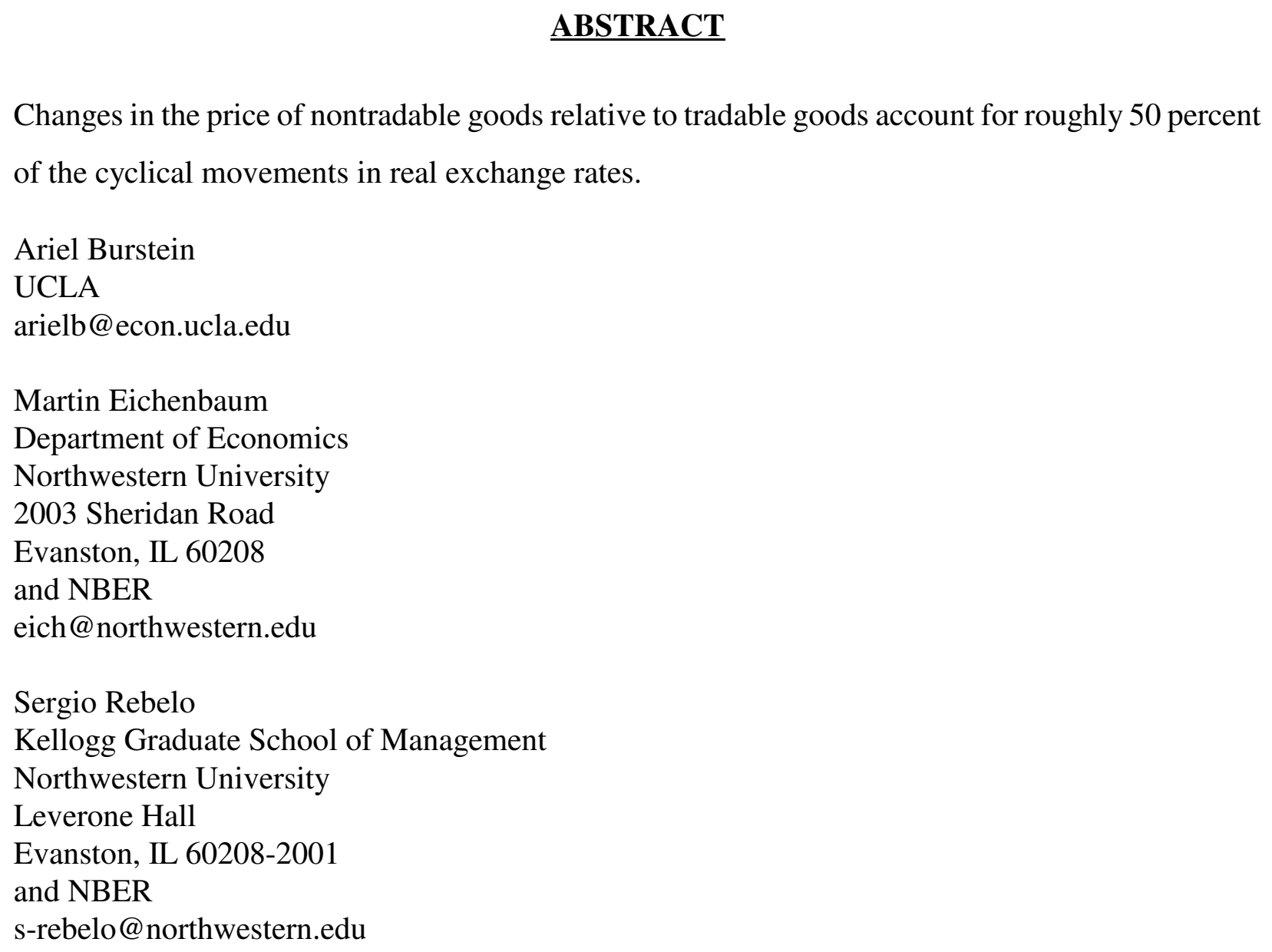




\section{Introduction}

A classic question in international macroeconomics is whether fluctuations in the real exchange rate $\left(R E R^{c p i}\right)$ constructed using the consumer price index (CPI) are primarily associated with movements in the relative price of tradable goods across countries or with fluctuations in the relative price of nontradable to tradable goods. Engel (1999) and Chari, Kehoe, and McGrattan (2002) conclude that fluctuations in the real exchange rates of developed economies are almost exclusively driven by changes in the relative price of tradable goods across countries. Their evidence suggests it is not important to distinguish between tradable and nontradable goods to understand cyclical real exchange rate fluctuations.

We argue that fluctuations in the relative price of nontradable to tradable goods are an important source of $R E R^{c p i}$ movements. We use an approach proposed by Engel (1999) and decompose the variance of $R E R^{c p i}$ into the variance of the relative price of tradable goods across countries, the variance in the relative price of nontradable to tradable goods, and a covariance term. To implement this decomposition we must take a stand on how to measure prices of tradable

goods. A standard approach in the literature is to use retail prices. Unfortunately, retail prices are heavily contaminated by the cost of nontradable distribution services such as retailing, wholesaling, and transportation (see Burstein, Neves, and Rebelo (2003)). One approach to dealing with the distribution cost issue is to measure tradable goods' prices using the producer price index (PPI). However, a problem with the PPI is that it generally excludes import prices (IMF(2004)) and, for roughly one third of OECD countries, it also excludes export prices (MaitlandSmith (2000)). For this reason, we focus on the prices of pure-traded goods at the dock, i.e. the price of goods that are actually traded exclusive of distribu- 
tion costs. ${ }^{1}$ We measure the relative prices of pure-traded goods across countries using a weighted average of import and export price indices. We use quarterly data for 11 OECD countries for the period 1971 to 2002. We find that, for the median country, variations in the price of nontradable goods relative to the price of pure-traded goods account for over half the movements in $R E R^{c p i}{ }^{2}$

This finding depends critically on our measure of the price of tradable goods. To substantiate this statement we use U.S. data to decompose the variance of $R E R^{c p i}$ using two alternative measures of the price of tradable goods: the retail price of tradable goods and a weighted average of import and export prices. The first price measure implies that the relative price of nontradable to tradable goods accounts for virtually none of the variance of $R E R^{c p i}$. In sharp contrast, the second price measure implies that the relative price of nontradable to tradable goods accounts for at least 55 percent of the variance of $R E R^{c p i}$. Using the retail price of tradable goods leads one to overstate the fraction of cyclical $R E R^{c p i}$ fluctuations that are due to changes in the price of pure-traded goods across countries.

Viewed overall, our results suggest that a successful theory of real exchange rate fluctuations must incorporate changes across countries in the relative price of nontradable goods to pure-traded goods. At the same time, our results are consistent with the view that there are significant fluctuations in the relative price of pure-traded goods across countries. These fluctuations could reflect a variety of factors such as sticky prices and endogenous changes in real markups. In addi-

\footnotetext{
${ }^{1}$ In addition to including distribution costs, CPI-based retail prices differ from import and export prices because the former includes "local goods." These are goods that are produced solely for the domestic market and are not traded.

${ }^{2}$ Betts and Kehoe (2005) argue that movements in nontraded goods prices are important in explaining real exchange rate fluctuations. Their analysis is based on real exchange rates constructed using gross output deflators. These deflators are available only at an annual frequency, and they do not include the price of imported final goods.
} 
tion, different countries import and export different baskets of goods. Therefore, changes in the relative price of these goods lead to changes in the relative price of traded baskets and in the measured real exchange rate. Assessing the plausibility of these alternative hypotheses is an important objective of ongoing research.

The remainder of this paper is organized as follows. Section 2 describes the method that we use to decompose $R E R^{c p i}$ movements. We report our empirical results in Section 3. Section 4 concludes.

\section{Decomposing Real Exchange Rate Fluctuations}

We define the CPI-based real exchange rate as:

$$
R E R_{t}^{c p i}=\frac{P_{t}}{S_{t} P_{t}^{*}} .
$$

Here $S_{t}$ denotes the geometric-trade-weighted nominal exchange rate of the home country defined as units of local currency per unit of geometric-trade-weighted foreign currency. The variables $P_{t}$ and $P_{t}^{*}$ denote the level of the CPI in the home country and the geometric-trade-weighted CPI of foreign countries, respectively.

To implement Engel's (1999) approach, we assume that $P_{t}$ is computed as a geometric average of the price of tradable goods $\left(P_{t}^{T}\right)$ and the price of nontradable $\left(P_{t}^{N}\right)$ goods:

$$
P_{t}=\left(P_{t}^{T}\right)^{1-\omega}\left(P_{t}^{N}\right)^{\omega} .
$$

Similarly, we assume that the foreign CPI is given by:

$$
P_{t}^{*}=\left(P_{t}^{T *}\right)^{1-\omega^{*}}\left(P_{t}^{N *}\right)^{\omega^{*}},
$$

where $P_{t}^{T *}$ and $P_{t}^{N *}$ denote the foreign price of tradable and nontradable goods, respectively. The variables $\omega$ and $\omega^{*}$ represent the share of tradable goods in the domestic and foreign CPI baskets. 
We denote the logarithm of $R E R_{t}^{c p i}, R E R_{t}^{T}$, and $R E R_{t}^{N}$ by $\operatorname{rer}_{t}^{c p i}, \operatorname{rer}_{t}^{T}$, and $r e r_{t}^{N}$, respectively. We decompose $\operatorname{rer}_{t}^{c p i}$ as:

$$
\operatorname{rer}_{t}^{c p i}=\operatorname{rer}_{t}^{T}+\operatorname{rer}_{t}^{N}
$$

The first component, $\operatorname{rer}_{t}^{T}$, is an index of the extent to which the price of tradable goods is different across countries:

$$
\operatorname{rer}_{t}^{T}=\log \left[P_{t}^{T} /\left(S_{t} P_{t}^{T *}\right)\right]
$$

The second component, $\operatorname{rer}_{t}^{N}$, reflects the between-country difference of the relative price of nontradable goods to tradable goods:

$$
r e r_{t}^{N}=\omega \log \left(P_{t}^{N} / P_{t}^{T}\right)-\omega^{*} \log \left(P_{t}^{N *} / P_{t}^{T *}\right)
$$

Using (2.2) we can decompose the variance of $\operatorname{rer}_{t}^{c p i}$ as:

$$
\operatorname{var}\left(\operatorname{rer}_{t}^{c p i}\right)=\operatorname{var}\left(\operatorname{rer}_{t}^{T}\right)+\operatorname{var}\left(\operatorname{rer}_{t}^{N}\right)+2 \operatorname{cov}\left(\operatorname{rer}_{t}^{T}, \operatorname{rer}_{t}^{N}\right) .
$$

We construct empirical measures of $\operatorname{rer}_{t}^{c p i}$ and $\operatorname{rer}_{t}^{T}$ and compute $\operatorname{rer}_{t}^{N}$ as a residual, using the identity (2.2). We estimate the individual elements of equation (2.3). We compute a lower bound, $L^{N}$, on the importance of movements in $\operatorname{rer}_{t}^{N}$ by attributing the covariance term to fluctuations in the price of tradable (nontradable) goods when the estimated covariance is positive (negative):

$$
L^{N}=\left\{\begin{array}{cl}
\frac{\operatorname{var}\left(\operatorname{rer}_{t}^{N}\right)}{\operatorname{var}\left(\operatorname{rer}_{t}^{c p i}\right)} & \text { if } \operatorname{cov}\left(\operatorname{rer}_{t}^{T}, \operatorname{rer}_{t}^{N}\right)>0 \\
\frac{\operatorname{var}\left(\operatorname{rer}_{t}^{N}\right)}{\operatorname{var}\left(\operatorname{rer}_{t}^{c p i}\right)}+\frac{2 \operatorname{cov}\left(\operatorname{rer}_{t}^{T}, \operatorname{rer}_{t}^{N}\right)}{\operatorname{var}\left(\operatorname{rer}_{t}^{c p i}\right)} & \text { if } \operatorname{cov}\left(\operatorname{rer}_{t}^{T}, \operatorname{rer}_{t}^{N}\right)<0
\end{array}\right.
$$

We compute an upper bound, $U^{N}$, on the importance of movements in $\operatorname{rer}^{N}$ by attributing the estimated covariance term to fluctuations in the price of nontradable (tradable) goods when the estimated covariance is positive (negative): 


$$
U^{N}=\left\{\begin{array}{cc}
\frac{\operatorname{var}\left(\operatorname{rer}_{t}^{N}\right)}{\operatorname{var}\left(\operatorname{rer}_{t}^{c p i}\right)}+\frac{2 \operatorname{cov}\left(\operatorname{rer}_{t}^{T}, \operatorname{rer}_{t}^{N}\right)}{\operatorname{var}\left(\operatorname{rer}_{t}^{c i}\right)} & \text { if } \operatorname{cov}\left(\operatorname{rer}_{t}^{T}, \operatorname{rer}_{t}^{N}\right)>0, \\
\frac{\operatorname{var}\left(\operatorname{rer}_{t}^{N}\right)}{\operatorname{var}\left(\operatorname{rer}_{t}^{c p i}\right)} & \text { if } \operatorname{cov}\left(\operatorname{rer}_{t}^{T}, \operatorname{rer}_{t}^{N}\right)<0 .
\end{array}\right.
$$

A key empirical question in implementing (2.2) is: how should we measure $P_{t}^{T}$ ? The most common approach in the literature is to measure $P_{t}^{T}$ using CPIbased retail prices of tradable goods. In contrast, we measure the price of tradable goods using the price of pure-traded goods at the dock. Specifically, we use an equally weighted geometric average of import and export price indices. ${ }^{3}$ These indices have two important advantages relative to retail prices and the PPI. First, import and export indices measure the prices of goods that are actually traded. Second, these indices are much less contaminated by nontradable components such as distribution costs.

We use quarterly data covering the period 1971.Q1 to 2002.Q3 for 11 countries: Australia, Canada, Denmark, Finland, Germany, Italy, Japan, the Netherlands, Sweden, UK, and the U.S. All price series (nominal exchange rates, consumer price indices, import and export price indices) are from the IMF's International Financial Statistics. We measure $S_{t}, P_{t}^{*}$ and $P_{t}^{T *}$ as trade-weighed averages of the individual country price series. ${ }^{4}$ To isolate cyclical frequencies we detrend the

\footnotetext{
${ }^{3}$ We use import and export price indices when possible, and unit values when price indices are not available. For Denmark, where only import price indices are available, we assume that the export price index is equal to the import price index.

${ }^{4}$ The trade share of country $i$ from country $j$ is calculated as $0.5 \operatorname{exports}_{j}^{i} / \operatorname{exports}^{i}+0.5$ imports $_{j}^{i} /$ imports $^{i}$, where exports ${ }_{j}^{i}$ and imports ${ }_{j}^{i}$ denote total exports and imports of country $i$, respectively, exports ${ }_{j}^{i}$ denotes exports of country $i$ to country $j$, respectively, and imports ${ }_{j}^{i}$ denotes imports of country $i$ from country $j$, respectively. We obtain import and export data from the IMF's Direction of Trade Statistics. Export and import shares are computed as simple averages using annual data from 1980 to 2002. For each country in our sample we choose the set of 20 countries with which this country has the highest trade share. We then eliminate those countries for which we do not have import and export price indices. The remaining 17 countries are: Australia, Canada, Denmark, Finland, Germany, Greece, Italy, Japan, Korea,
} 
logarithm of all time series using the Hodrick-Prescott filter using a smoothing parameter of 1600 .

Despite their advantages, there are three caveats about import and export price indices that are worth noting. First, some of the import and export prices used in the construction of these indices can reflect transfer prices within multinational corporations instead of market transactions. Second, import and export indices include investment, intermediate goods, and raw materials as well as consumption goods. ${ }^{5}$ Finally, for Denmark, Italy and Germany, import and export price indices are based on unit value indices (UVIs) computed from trade statistics as the ratio of the local currency value of exports or imports to volume (weight or quantity). A potential problem with UVIs is that they are affected by shifts over time in product composition.

\section{Empirical Results}

Figure 1 displays the time series of $\log \left(S_{t}\right), \operatorname{rer}_{t}^{c p i}$, and $\operatorname{rer}_{t}^{T}$ for 11 countries. We normalize the level of these variables to zero in 1972the beginning of the sample. It is evident that $r e r_{t}^{c p i}$ and $\operatorname{rer}_{t}^{T}$ behave quite differently. These differences are particularly pronounced for Australia, Italy, Japan, the Netherlands, and Sweden.

The first panel of Table 1 displays summary statistics of the data. We compute three statistics for both $\operatorname{rer}_{t}^{c p i}$ and $\operatorname{rer}_{t}^{T}$ : the standard deviation, the correlation with $\log \left(S_{t}\right)$, and the elasticity with respect to $\log \left(S_{t}\right)$. The latter is the slope of a linear regression of the logarithm of either $\operatorname{rer}_{t}^{c p i}$ or $\operatorname{rer}_{t}^{T}$ on $\log \left(S_{t}\right)$. These elasticities do not have a causal or structural interpretation. However, they are a convenient way to summarize the quantitative relation between $\operatorname{rer}_{t}^{c p i}, \operatorname{rer}_{t}^{T}$, and

Mexico, Netherlands, Spain, Sweden, Switzerland, UK, U.S., and Venezuela. For the median country, our trade weights account for 57 percent of total imports and exports.

${ }^{5}$ See Burstein, Eichenbaum, and Rebelo (2005) for a discussion of the second caveat. 
nominal exchange rates.

Consistent with Mussa (1986) we find that there is a very strong correlation between the logarithm of the nominal exchange rate and $\operatorname{rer}_{t}^{c p i}$. The median correlation between these two series is -0.96 . The volatility of these series is also very similar. The median value of the ratio of the standard deviations of $\operatorname{rer}_{t}^{c p i}$ and $\log \left(S_{t}\right)$ is 1.03. The median value of the elasticity of the $\operatorname{rer}_{t}^{c p i}$ and $\operatorname{rer}_{t}^{T}$ with respect to $\log \left(S_{t}\right)$ is -0.99 . Taken together our summary statistics suggest a very tight relation between $\operatorname{rer}_{t}^{c p i}$ and $\log \left(S_{t}\right)$. One widely held interpretation of this tight relation is that it reflects the pervasiveness of sticky prices, with no distinction being made between tradable and nontradable goods.

Next we consider our summary statistics for $\operatorname{rer}_{t}^{T}$. The median correlation between $\operatorname{rer}_{t}^{T}$ and $\log \left(S_{t}\right)$ is -0.69 , while the median value of the ratio of the standard deviations of these two series is 0.62 . Finally, the elasticity of $\operatorname{rer}_{t}^{T}$ with respect to $\log \left(S_{t}\right)$ is only -0.41 . Clearly, the relation between $\operatorname{rer}_{t}^{T}$ and $\log \left(S_{t}\right)$ is substantially weaker than the relation between $\operatorname{rer}_{t}^{c p i}$ and $\log \left(S_{t}\right)$.

We now examine the role of tradable and nontradable goods prices in accounting for movements in the real exchange rate. The last two columns of Table 1 report the lower and upper bounds for the importance of movements in nontradable goods prices as sources of $\mathrm{rer}_{t}^{c p i}$ fluctuations, defined in (2.4) and (2.5). The median values of these bounds are 52 and 68 percent. We redo our calculations measuring the price of pure-traded goods using only the price of imported goods. In this case we find that the median values of $L^{N}$ and $L^{U}$ are 49 and 82 percent, respectively. We infer that movements in the price of nontradable goods relative to tradable goods are important, accounting for more than half of the fluctuations in $\operatorname{rer}_{t}^{c p i}$.

This finding stands in sharp contrast with the results in the literature obtained using retail prices to measure $P_{t}^{T}$ and $P_{t}^{T *}$ (see Engel (1999) and Chari, Kehoe, 
and McGrattan (2002)). We illustrate the contrast by estimating the lower and upper bounds defined in (2.4) and (2.5) for the U.S. using two alternative measures of tradable goods' prices.

In the first case we measure $P_{t}^{T}$ using an equally weighted geometric average of U.S. import and export price indices. We measure $P_{t}^{T *}$ using a trade-weighted, equally-weighted geometric average of import and export price indices for the following trading partners of the U.S.: Australia, Canada, Germany, Italy, Japan, Korea, Mexico, the Netherlands, Spain, Switzerland, UK, and Venezuela. Together these countries account for 64 percent of U.S. imports and exports for the period 1980 to 2001.

In the second case we measure $P_{t}^{T}$ using the retail price of tradable goods in the U.S. We average monthly data on the retail price of tradable goods obtained from the Bureau of Labor Statistics to produce a quarterly time series. We construct $P_{t}^{T *}$ as a trade-weighted average of the U.S. trading partners' consumer prices. For Canada, Italy, Japan, and Mexico we use the retail prices of tradable goods. These countries account for 43 percent of U.S. trade during the period 1980 to 2001. Due to data limitations, for Australia, Germany, Korea, the Netherlands, Spain, Switzerland, the UK, and Venezuela we measure the price of tradable goods using the CPI. The sample period, 1975.Q1 to 2002.Q3, which differs from that of the data used to construct Table 1, was dictated by the availability of retail prices of tradable goods for some of the U.S. trading partners. We report our results in Table 2.

Consistent with the results in Table 1, when $P_{t}^{T}$ is measured using import and export prices fluctuations in nontradable goods prices account for well over half of the movements in $\mathrm{rer}_{t}^{c p i}$. In sharp contrast, when $P_{t}^{T}$ is measured using retail prices, these fluctuations account for 5 percent or less of the movements in the $\operatorname{rer}_{t}^{c p i}$. 
Taken together, our results make clear that the conventional view that movements in nontradable goods prices are unimportant as sources of cyclical $R E R^{c p i}$ fluctuations, depends critically on the questionable assumption that the price of tradable goods can be accurately measured using retail prices. Measuring the price of tradable goods using retail prices understates the importance of movements in the relative price of nontradable goods as a source of cyclical $R E R^{c p i}$ fluctuations.

\section{Conclusion}

Burstein, Eichenbaum, and Rebelo (2005) argue that in the aftermath of large devaluations, changes in the real exchange rate are overwhelmingly driven by movements in the price of nontradable goods relative to the price of pure-traded goods. This paper analyses the source of real exchange rate fluctuations at cyclical frequencies. We find that more than half of these fluctuations are accounted for by movements in the price of nontradable goods relative to the price of pure-traded goods. The remaining half are due to movements in the relative price of traded goods across countries. Understanding the sources of these latter movements has been the focus of a large literature. Our findings suggest that equal attention should be paid to modeling movements in the relative price of nontradable to pure-traded goods. 


\section{References}

[1] Betts, Caroline and Timothy Kehoe, "U.S. Real Exchange Rate Fluctuations and Relative Price Fluctuations," forthcoming Journal of Monetary Economics, 2005.

[2] Burstein, Ariel, Martin Eichenbaum and Sergio Rebelo, "Large Devaluations and the Real Exchange Rate," Journal of Political Economy, 113: 742-784, 2005.

[3] Burstein, Ariel, Joao Neves, and Sergio Rebelo, "Distribution Costs and Real Exchange-Rate Dynamics During Exchange-Rate-Based Stabilizations," Journal of Monetary Economics, 50: 1189-1214, 2003.

[4] Chari, V. V., Patrick Kehoe, and Ellen McGrattan, "Can Sticky Price Models Generate Volatile and Persistent Real Exchange Rates?," Review of Economic Studies, 69: 533-563, 2002.

[5] Engel, Charles, "Accounting for U.S. Real Exchange-rate Changes," Journal of Political Economy, 107: 507-538, 1999.

[6] International Monetary Fund, "Producer Price Index Manual: Theory and Practice," 2004.

[7] Maitland-Smith, Fenella "Producer Price Indices," mimeo, OECD, 2000.

[8] Mussa, Michael, "Nominal Exchange-rate Regimes and the Behavior of Real Exchange Rates: Evidence and Implications," Carnegie-Rochester Series on Public Policy, 25: 117-214, 1986. 
TABLE 1

Quarterly Data, 1971.Q1-2002.Q3 (HP-Filtered)

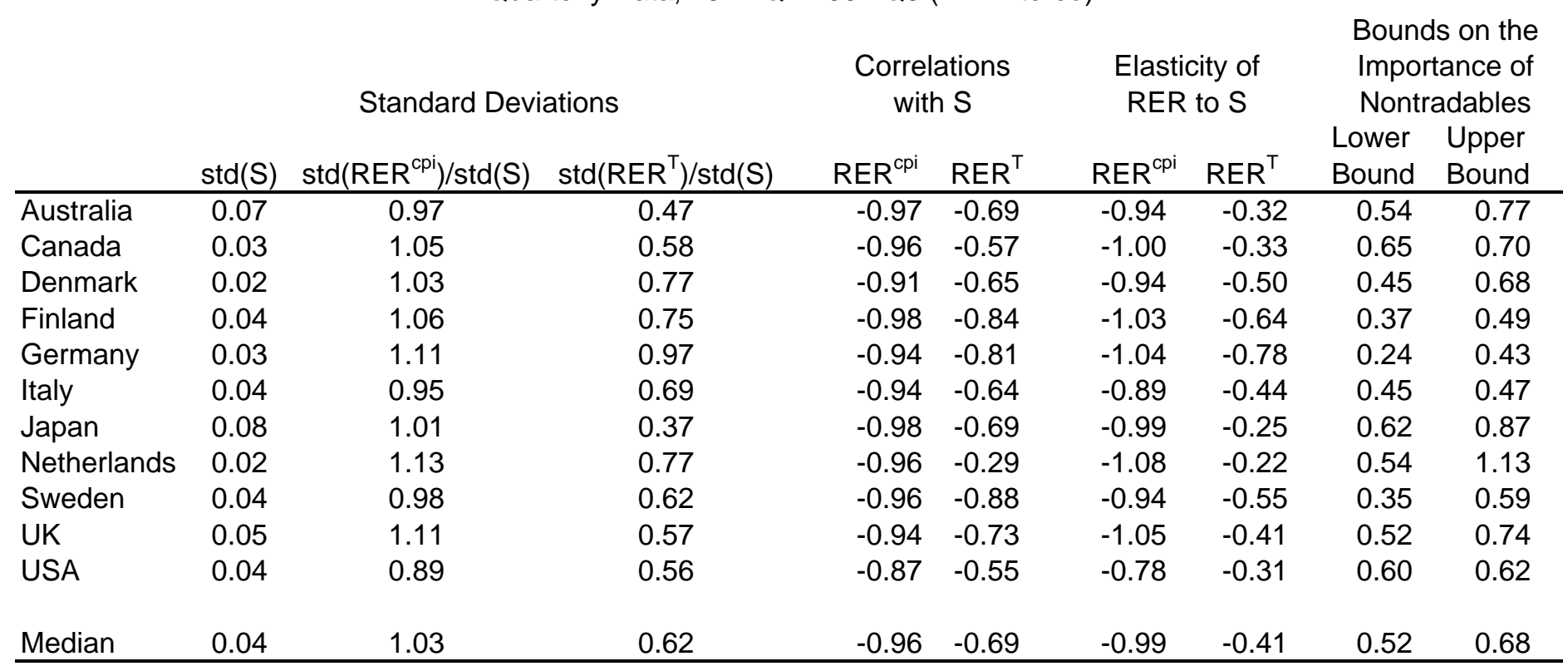


TABLE 2

U.S. Quarterly Data 1975.Q1-2002.Q3 (HP-Filtered)

Lower Bound on the Upper Bound on the

Importance of Non- Importance of Non-

Tradables

Tradables

$\mathrm{P}^{\top}$ measured using Import

and Export Prices

0.56

0.71

$\mathrm{P}^{\top}$ measured using Retail

Prices

$-0.05$

0.05 
Figure 1
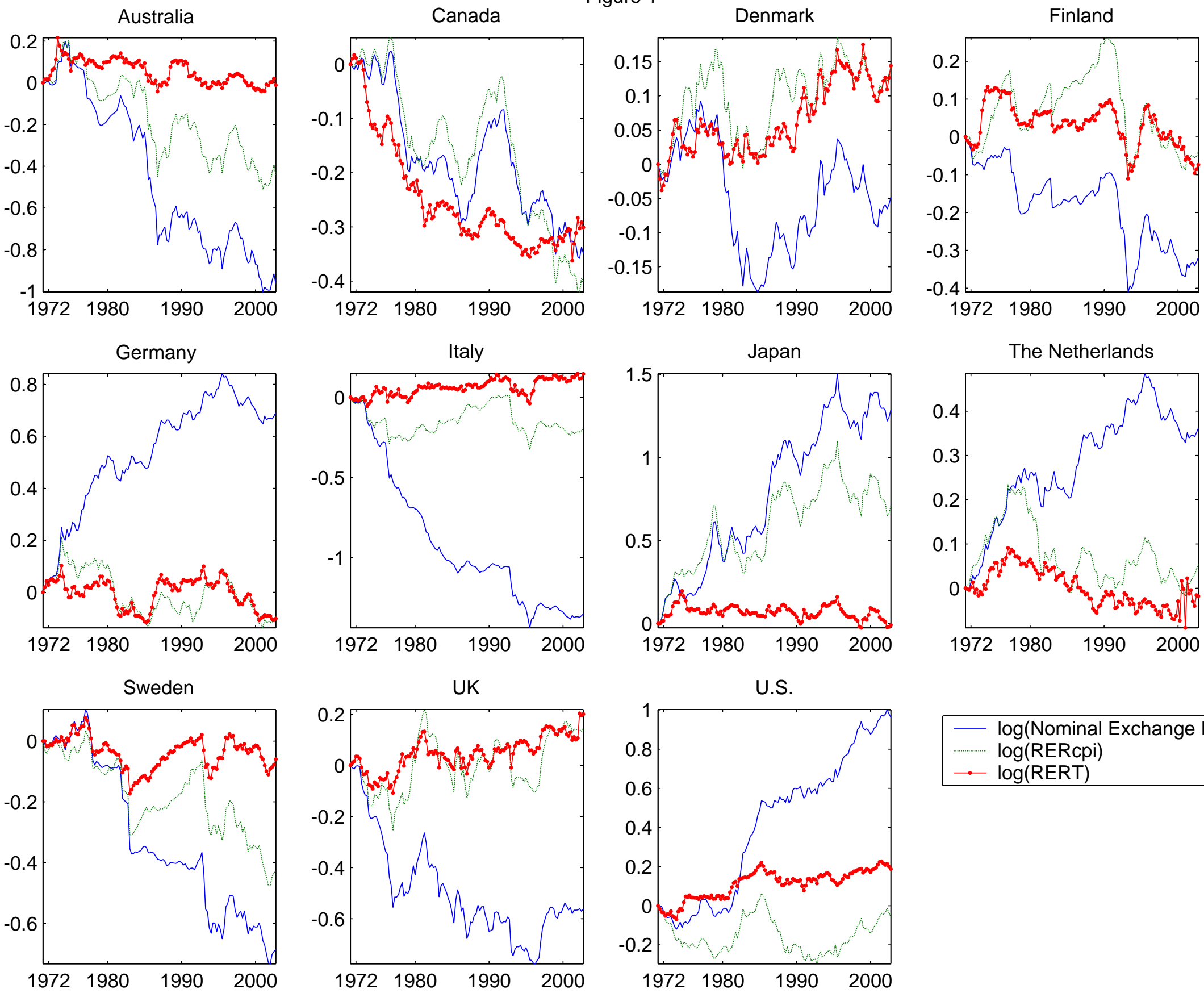
- $\log$ (Nominal Exchange Rate) log(RERcpi) - $\log$ (RERT)

